\title{
MINERAL RESOURCE POTENTIAL AND GEOLOGY OF GUADALUPE ESCARPMENT WILDERNESS STUDY AREA, EDDY COUNTY, NEW MEXICO
}

\author{
By \\ Philip T. Hayes and Thomas D. Light, U.S. Geological Survey \\ and \\ John R. Thompson, U.S. Bureau of Mines
}

\section{STUDIES RELATED TO WILDERNESS}

Under the provisions of the Wilderness Act (Public Law 88-577, September 3, 1964) and related acts, the U.S. Geological Survey and the U.S. Bureau of Mines have been conducting mineral surveys of wilderness and primitive areas. Areas officially designated as "wilderness," "wild," or "canoe" when the act was passed were incorporated into the National Wilderness Preservation System, and some of them are presently being studied. The act provided that areas under consideration for wilderness designation should be studied for suitability for incorporation into the Wilderness System. The mineral surveys constitute one aspect of the suitability studies. The act directs that the results of such surveys are to be made available to the public and be submitted to the President and the Congress. This report discusses the results of a mineral survey of the Guadalupe Escarpment Wilderness Study Area, Lincoln National Forest, Eddy County, New Mexico. The area was established as a wilderness study area by Public Law 96-550, December 1980.

\section{MINERAL RESOURCE POTENTIAL SUMMARY STATEMENT}

The geologic and geochemical investigations did not reveal any minable metal deposits within the study area, but a low to moderate potential exists for undiscovered base-metal deposits being present in the Seven Rivers and, perhaps, the Yates Formations. The Capitan Limestone may offer potential as cement limestone although it would be difficult and expensive to quarry. Two canyons contain gravel resources; however, more accessible gravels in the region are not exhausted. The oil and gas potential of the study area is moderate; drilling data from surrounding areas indicate that the study area is underlain by thousands of feet of strata that could contain stratigraphic or structural traps for oil and (or) gas. Both oil and gas are produced from Pennsylvanian rocks about $10 \mathrm{mi}$ east of the study area and oil has been discovered in lower Permian strata about 5 mi east of the study area.

\section{INTRODUCTION}

Location, Size, and Geographic Setting

The Guadalupe Escarpment Wilderness Study Area comprises about $34 \mathrm{mi}^{2}$ (21,300 acres) in Lincoln National Forest, Eddy County, N. Mex. It adjoins Guadalupe Mountains National Park on the south and Carlsbad Caverns National Park on the east. The study area is characterized by deep, rugged canyons that trend southeasterly from Guadalupe Ridge through the Guadalupe Escarpment; these canyons all drain to western tributaries of the Pecos River. The highest elevation above sea level is about $7,480 \mathrm{ft}$ and the lowest elevation is about $4,875 \mathrm{ft}$. A rough jeep road along the northwest boundary of the study area can be reached by U.S. Forest Service roads from the northwest. The southeast part of the study area can be approached via unimproved ranch roads leading off U.S. Highway 62-180 (fig. 1).
Previous and Present Studies

Because the Guadalupe Escarpment Wilderness Study Area ind adjoining parts of Carlsbad Caverns and Guadalupe Mountains National Parks contain excellent exposures of the remarkable lateral facies changes between the famous Capitan Limestone and its shelf equivalents to the northwest, the area has been studied by geologists for more than 50 years. However, the only moderately detailed published geologic maps of all or parts of the present study area are those of King (1948), Hayes and Koogle (1958), and Hayes (1964). An accounting of the numerous detailed stratigraphic, paleontologic, and sedimentological studies of the area, many of which are excellent, is not undertaken here.

During the fall of 1981 and the spring of 1982 , the U.S. Geological Survey and the U.S. Bureau of Mines conducted a mineral resource appraisal of the Guadalupe Escarpment Wilderness Study Area. This 


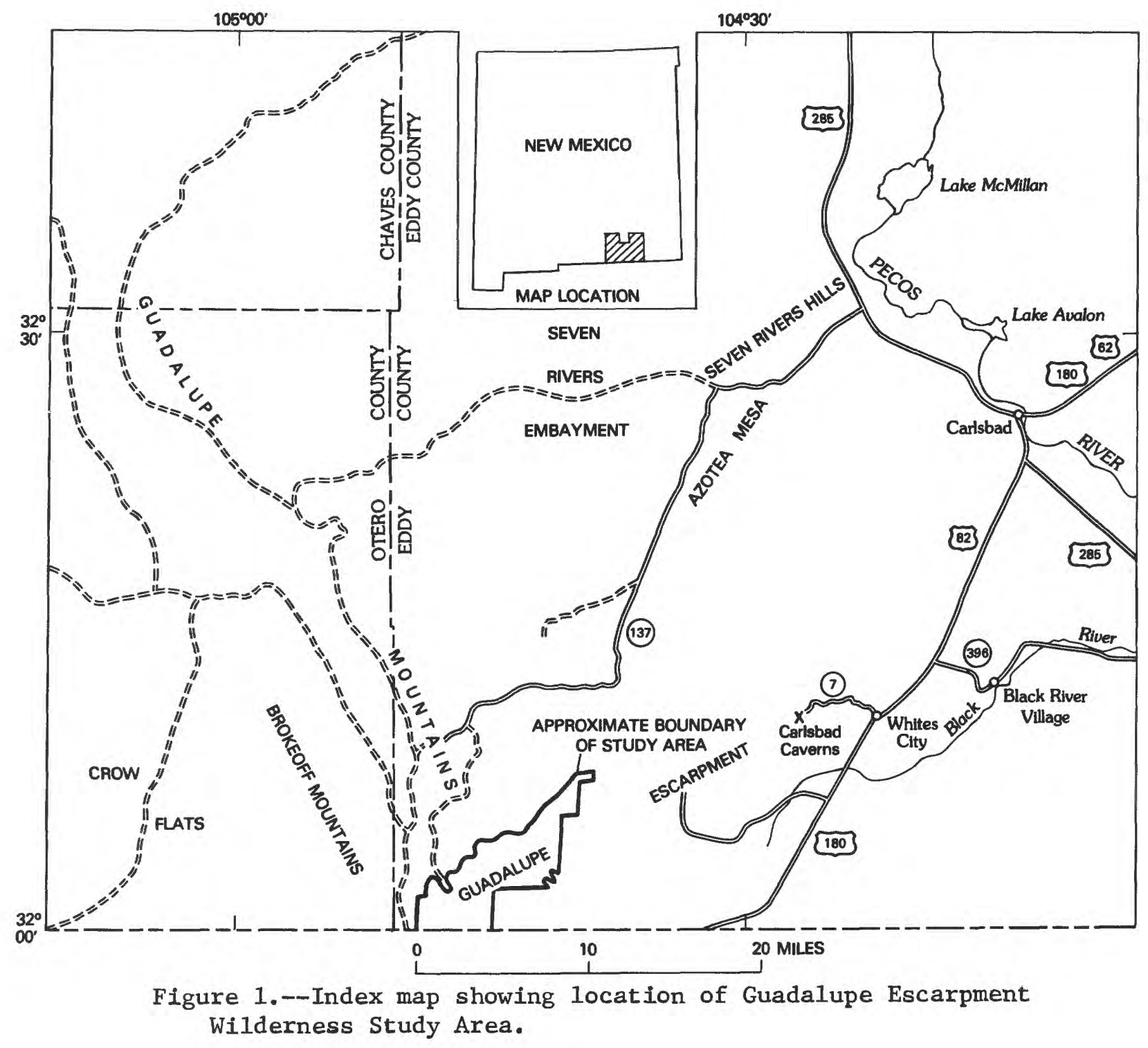


report summarizes the findings and includes a mineral resource potential map of the study area.

The present study included: preparation of a geologic map and a search for field evidence of mineralized rock by Hayes in the spring of 1982 , a survey and appraisal of mines and prospects in and near the study area by J. R. Thompson (unpub. data, 1981) in the fall of 1981, and a geochemical study of the area by T. D. Light and others (unpub. data, 1982), and Light and Domenico (1983) in the spring of 1982.

\section{GEOLOGIC SETTING}

The mapped area is known for its display of the remarkable lateral facies changes from the Capitan Limestone to equivalent shelf carbonates. The Capitan Limestone is divided into two members: the massive member (Hayes, 1964) or reef facies (Newell and others, 1953), and the breccia member (Hayes, 1964) or reef-talus facies (Newell and others, 1953). The massive member has generally been interpreted to be a barrier reef or bank deposit that grew along the margin of the subsiding Delaware basin to the southeast. The breccia member, which is largely made up of debris of the massive member, lies southeast of the massive member. The breccia member is marked by thick, crudely defined beds that dip southeasterly at roughly $30^{\circ}$ and grade rather abruptly into the less steeply dipping, thin-bedded bioclastic limestones of the Bell Canyon Formation. Parts of this transition are displayed outside the study area near the mouths of Big and Franks Canyons. The massive member grades northwestward into carbonates of the Tansill, Yates, and Seven Rivers Formations. The gradational contacts are placed roughly where bedding becomes discernible in the shelf carbonates, which also approximately coincides with the place where the carbonates change from limestone in the southeast to dolomitic limestone or calcareous dolomite in the northwest, and to the place where sandstone and siltstone beds of the shelf units pinch out southeastward. The Tansill, Yates, and Seven Rivers Formations display internal facies changes between their boundaries with the Capitan Limestone and the northwest edge of the mapped area. The bedding of the carbonate rocks becomes thinner northwestward, and sandstone and siltstone beds (primarily in the Yates Formation) become thicker northwestward; the fabric of the carbonates also changes northwestward. The older Goat Seep Dolomite, except for being dolomitic, is similar to the Capitan Limestone; and the Queen and Grayburg Formations, into which the Goat Seep grades northwestward, are comparable to the Tansill, Yates, and Seven Rivers Formations.

Although other dramatic pinchouts and facies changes are not exposed within the mapped area, exposures to the west and southwest and drill-hole information suggest that they probably occur in the thousands of feet of Permian rocks that lie beneath the mapped area. Facies changes and pinchouts probably occur in Pennsylvanian rocks as well. These could contain traps for oil and gas.

The Guadalupe Mountains, in which the Guadalupe Escarpment Wilderness Study Area lies, are a gently tilted fault-block range that was elevated along a series of generally north-trending normal faults in Tertiary time. One of these faults (down on the west) lies in the west part of the mapped area and is barely within a corner of the study area. In addition to the gentle eastward regional dip imposed on the rocks by the mountain uplift, the rocks have been gently folded; Guadalupe Ridge (fig. 2) approximately defines the crest of a northwest-trending anticline.

\section{GEOCHEMISTRY}

Geochemical data for stream-\$ediment and rock samples from the Guadalupe Escarpment Wilderness Study Area are contained in a report by Light and Domenico (1983). Nonmagnetic heavy-mineral concentrates from stream sediments contain anomalous concentrations of barium, zinc, and cadmium throughout the study area. Many of the samples also contain anomalous concentrations of lead, molybdenum, copper, or boron (T. D. Light and others, unpub data, 1982). Zinc to cadmium ratios are consistently about 100 , indicating that although zinc is anomalously high, cadmium has been enriched relative to zinc.

Rock samples from iron-rich sandstone units in the Yates and Seven Rivers Formations contain anomalous amounts of zinc, arsenic, lead, cadmium, and molybdenum. Zinc, arsenic, and molybdenum were detected in samples from several localities throughout the study area; copper and silver were found in the Yates Formation on Lonesome Ridge.

The anomalous suite of elements observed in the study area is found near the limestone-dolomite interface in algal-reef rocks and is similar to geochemical associations observed in some Mississippi Valley-type barium-lead-zinc deposits (Snyder, 1968). This association may indicate the presence of stratabound epigenetic mineralization associated with fluids that migrated through the Yates and Seven Rivers Formations.

\section{MINING DISTRICTS AND MINERALIZED AREAS}

The Guadalupe Escarpment Wilderness Study Area has been prospected since the early 1900's. No patented claims and fewer than 10 unpatented claims have been staked in the study area. Two claims in the study area were on record with the U.S. Bureau of Land Management in October 1982. Most of the recent lode claims adjacent to the study area were located for copper, but older claims probably were staked for bat guano. In 1981, no mines or prospects were being worked within or adjacent to the study area.

No recognized mining districts are in the Guadalupe Escarpment Wilderness Study Area. Several mines and prospects were found in three weakly mineralized zones: two in the study area and one, a more heavily mineralized zone, squth of the study area. The mines outside the study area, in the Texas Calumet mining area (inside what is now the Guadalupe Mountains National Park, Tex.), were examined in detail because similar rocks are found within the study area. The only recorded production was from the Texas Calumet mines.

The two mineralized zones in the study area are close to the western boundary. The northern mineralized zone (J. R. Thompson, unpub. data, 1981) is bounded on the north by the portheast-trending 


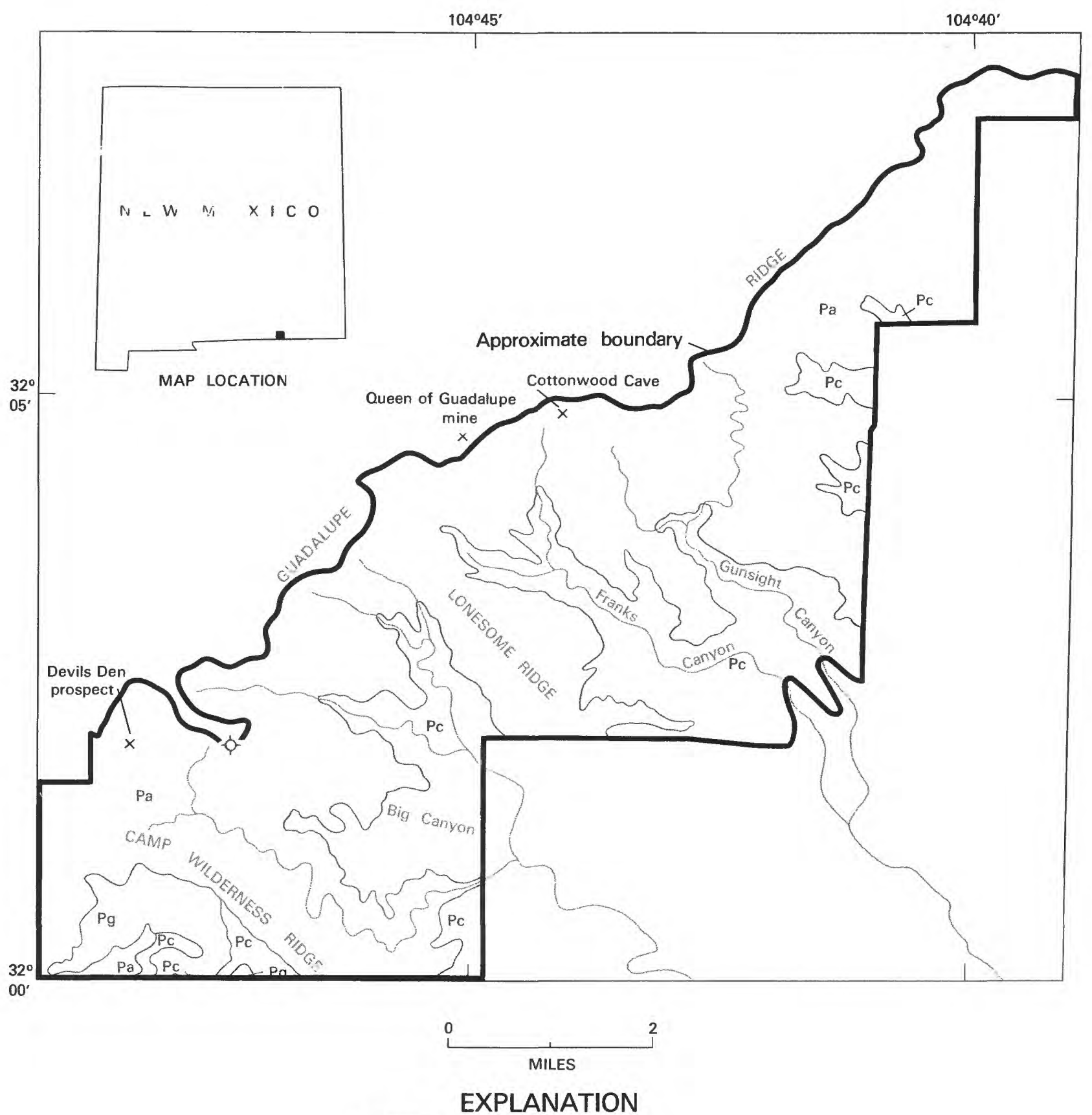

\begin{tabular}{|c|c|}
\hline $\mathrm{Pa}$ & Artesia Group (Permian) \\
\hline $\mathrm{Pc}$ & Capitan Limestone (Permian) \\
\hline $\mathrm{Pg}$ & Goat Seep Dolomite (Permian) \\
\hline & Contact \\
\hline$-\phi-$ & Abandoned oil and gas test hole \\
\hline
\end{tabular}

Figure 2.--Map of Guadalupe Escarpment Wilderness Study Area showing prospects, abandoned oil and gas test hole, and some geographic features mentioned in text. 
Guadalupe Ridge anticline and on the south by the northeast-trending Walnut Canyon syncline (Hayes, 1964 , p. 40 ). Associated with these structures are perpendictlar tension joints that for:ned channels along which ground water could pass.

The northern mineralized zone was explored by four prospect pits dug into the Seven Rivers Formation where a thin bed of highly iron-stained sandstone crops out. A shaft, known as the Queen of the Guadalupe mine, is in sandstone of the Seven Rivers Formation and intersects a vertical limestone cave. At the shaft, some azurite, malachite, bornite, and abundant hematite were identified. A prospect adit in Fir Canyon was driven into rocks near the base of the Seven Rivers Formation where pisolitic dolomite, exhibiting slight iron-oxide staining, is exposed.

Analyses of three chip samples and three random dump samples at the northern mineralized zone showed no gold or silver and low values of copper and other metallic minerals (J. R. Thompson, unpub. data, 1981).

The southern mineralized zone (Devils Den prospect), about $5 \mathrm{mi}$ southwest of the northern area (J. R. Thompson, unpub. data, 1981), is also bounded by the Guadalupe Ridge anticline and the Walnut Canyon syncline. The most important feature of Devils Den prospect is its proximity to a north-trending frontal fault that forms the Shattuck Valley scarp. The frontal fault can be traced into Dog Canyon, Tex., and is very near the Texas Calumet area $2 \mathrm{mi}$ south of the mapped area.

The southern mineralized zone has been explored by a prospect and adit in the Broken Horseshoe claim. The adit was driven $48 \mathrm{ft}$ into dolomite of the Seven Rivers Formation where some azurite and malachite staining and small amounts of earthy and specular hematite are exposed. A 21-ft-deep shaft was dug on a vertical fault in iron-stained sandstone of the Yates Formation. Analysis of three chip samples from the prospect, adit, and shaft and one sample from the dump showed no gold or silver and low values of copper and other metallic minerals (J. R. Thompson, unpub. data, 1981). The weak mineralization may be related to ground water solutions passing along the frontal fault.

The third mineralized zone, the more heavily mineralized zone at the Texas Calumet workings, $2 \mathrm{mi}$ south of the southwest corner of the study area, is on a graben created by the major Dog Canyon fault (King, 1948, p. 110). The mineralized zone contains four adits driven into dolomite of the Seven Rivers Formation. The dolomite contains epigenetic deposits of copper and iron along thin fault zones. Northwesttrending vertical faults contain hematite, azurite, and malachite. The thin mineralized faults of the Texas Calumet mines were probably spurs of the major Dog Canyon fault. The mineralizing fluids along the Dog Canyon fault were probably more metal rich than solutions along joints or other faults in the area. Projections of these faults do not enter the study area.

Records show that in 1914 and 1926-27, approximately 66 tons of ore, containing 6,256 lbs of copper and 3 oz of silver, were mined from the Texas Calumet mines (Lasky and Wooten, 1933, p. 46). Thirteen chip samples and one dump sample contained no gold or silver, but copper, lead, and zinc were present (J. R. Thompson, unpub. data, 1981).

\section{ASSESSMENT OF MINERAL RESOURCE POTENTIAL}

\section{Metalliferous Deposits}

Low to moderate potential exists for concealed base-metal deposits in the study area. The existence of copper minerals in the Seven Rivers Formation at the Devil's Den prospect (fig. 2) and the presence of more intensely mineralized rock in the Seven Rivers Formation a few miles south of the study area suggest that undiscovered mineralized rock could exist in the Seven Rivers Formation within the study area. Geochemical anomalies indicate that weakly mineralized epigenetic fluids migrating through the Permian carbonate rocks have concentrated base metals in the Seven Rivers and Yates Formations. The potential for these fluids to have concentrated sufficient quantity or grade of metals to be of economic interest within the Guadalupe Escarpment Wilderness Study Area is probably low.

\section{Nonmetalliferous Deposits}

Nonmetalliferous deposits that may offer low potential are limestone, gravel, and guano. These are briefly discussed in order of decreasing potential.

Most of the carbonate rocks in the study area are too dolomitic or impure to be of potential value as cement limestone and are too calcitic to be of potential value as high-purity dolomite. The massive member of the Capitan Limestone, however, may be low enough in magnesia and silica to offer some potential as cement limestone. The lack of bedding planes in that unit, combined with its usual location high in canyon walls, would make quarrying difficult and expensive. Some of the bedded dolomites of the Tansill, Yates, and Seven Rivers Formations might be suitable for low-value building stone.

Limestone gravel in alluvial stream deposits is abundant near the mouths of all the large canyons that cut through the Guadalupe Escarpment. All of the deposits that offer the greatest potential lie outside the boundary of the study area, but some in Franks and Gunsight Canyons (fig. 2) might be exploitable in the future if gravels that are closer to markets have been exhausted.

Guano is found in small amounts in Cottonwood Cave (fig. 2) and possibly in other small solution caves in the study area. Guano was formerly mined as nitrate-rich fertilizer from caves now in Carlsbad Caverns National Park, but now that most fertilizer nitrate is being obtained from the destructive distillation of coal and coke, from sewage treatment plants, and by fixation from the atmosphere, little present or foreseeable demand exists for guano except for that which is found in large, easily mined deposits. Therefore, the guano that exists in the study area is considered of negligible importance.

\section{Oil and Gas}

The potential for oil and gas beneath the study area is moderate. Both oil and gas are presently produced from Pennsylvanian rocks about $10 \mathrm{mi}$ east of the northern part of the study area, and oil has been discovered in Lower Permian strata less than 5 mi east of the study area. On the other hand, about a dozen 
wildcat holes located in the Guadalupe Mountains within 10 mi north of the study area have been drilled into or through Pennsylvanian rocks without success. Information from wells indicates that lithologic facies changes in Pennsylvanian and Lower Permian rocks beneath the study area possibly provide stratigraphic traps suitable for oil and gas accumulation. Guadalupe Ridge lies along the approximate crest of an anticline, another possible trap. However, one unsuccessful hole has been drilled on that anticline on the western edge of the study area (fig. 2) in sec. 22, T. 26 S., R. 21 E. In spite of that hole, the study area itself can be said to be virtually untested.

\section{REFERENCES CITED}

Hayes, P. T., 1964, Geology of the Guadalupe Mountains, New Mexico: U.S. Geological Survey Professional Paper 446, 69 p.

Hayes, P. T., and Koogle, R. L., 1958, Geology of the Carlsbad Caverns West quadrangle: U.S. Geological Survey Geologic Quadrangle Map GQ112 , scale $1: 62,500$.
King, P. B., 1948, Geology of the southern Guadalupe Mountains, Texas: U.S. Geological Survey Professional Paper 215, 183 p.

Lasky, S. G., and Wooten, P. T., 1933, The metal resources of New Mexico and their economic features: New Mexico School of Mines Bulletin $7,178 \mathrm{p}$.

Light, T. D., and Domenico, J. A., 1983, Geochemical data for the Guadalupe Escarpment Wilderness Study Area, Eddy County, New Mexico: U.S. Geological Survey Open-File Report 83-7, 20 p.

Newell, N. D., Rigby, J. K., Fischer, A. G., Whiteman, A. J., Hickox, J. E., and Bradley, J. S., 1953, The Permian reef complex of the Guadalupe Mountains region, Texas and New Mexico-a study in paleoecology: San Francisco, W. $\mathrm{H}$. Freeman \& Co., 236 p.

Snyder, F. G., 1968, Geology and mineral deposits, midcontinent United States, in Ore deposits of the United States, 1933-1967 (v. 1): New York, American Institute of Mining, Metallurgical, and Petroleum Engineers, p. 257-286. 